\title{
Indigenous Australian women promoting health through sport
}

\author{
Megan Stronacha, Hazel Maxwell ${ }^{b}$, and Sonya Pearce ${ }^{c}$
}

\author{
a Dr. Megan Stronach, University of Technology Sydney, Ultimo Road, Sydney NSW 2007. \\ megan.stronach@uts.edu.au \\ ${ }^{\mathrm{b}}$ Dr. Hazel Maxwell, University of Tasmania, Church St, Lilyfield NSW 2040. \\ hazel.maxwell@utas.edu.au \\ ${ }^{c}$ Dr. Sonya Pearce, Tranby Indigenous College, 13 Mansfield St, Glebe NSW 2037.
}

\section{Highlights}

- There are health disparities between Indigenous and non-Indigenous Australians

- Indigenous women are keen to seek support and opportunities which will serve to improve their health.

- Agency and empowerment will enable women to self-manage their health concerns

- Partnerships between health agencies and sport organisations may improve these disparities. 


\title{
Indigenous Australian women, promoting health through sport
}

\begin{abstract}
This paper explores the sporting experiences and community strengths of Indigenous Australian women. The intention is to inform both health promotion and contemporary sport management strategies, and policies and practices, leading to better health outcomes for this cohort. The study uses an interpretative qualitative methodology which involves the combination of data from a range of sources, including interviews and focus groups with 22 Indigenous women living in urban and rural areas, narratives from elite Indigenous athletes and coaches, as well as findings from a recent Australian Parliamentary inquiry into Indigenous health and wellbeing. The research utilises an agency/empowerment theoretical framework. Embracing this approach leads the authors to posit that, given support and opportunities, Indigenous women can become empowered to improve their mental and physical health through participation in sport. Sport managers can facilitate Indigenous women's agency in the effects of colonisation, which continues to be the basis of health issues for this cohort. This can be achieved by listening to Indigenous women, and then facilitating opportunities for them to take control of their own participation-and that of other women in their communities. Indigenous-women's only opportunities, partnerships with health agencies and sports organisations, culturally safe spaces and Indigenous women acting as role models are some factors that may augment Indigenous women's agency, and thus empowerment. Government, sports, community organisations and health agencies which provide these conditions in their program design can help to overcome entrenched social, historical and health inequalities that Indigenous women may experience.
\end{abstract}

Key words: Indigenous, Australian, women, agency, empowerment, sport 


\section{Introduction}

Commonly, researchers, media and policy-makers focus on so-called deficits of Australian Indigenous people. However, there are many strengths and creative approaches within Indigenous communities which show imagination and innovation in addressing health problems. For example, established sports program such as the Deadly Sistas Girls Program, Gwabba Yorga, Gabba Warra and the Moorditj Mums (Maxwell, Stronach, Adair and Pearce 2017) feature strong female leadership and occur within safe, stable and trusting environments, where sport is considered a way of community. These programs are evidence of approaches which might be overlooked should a deficit lens be applied to this cohort. Successful female Indigenous athletes lead the way as role models for other Indigenous women in both the sporting arena and wider society. Two philanthropic foundations headed up by Indigenous women are the Cathy Freeman and the Evonne Goolagong Foundations. The recent appointment of Tanya Hosch (an Indigenous woman) to the board of the Australian Football League demonstrates the growing influence and recognition of Indigenous women in Australian sporting contexts. A consideration of the strengths and assets of Indigenous women, such as those mentioned here, is the underpinning approach of this paper.

Despite many success stories, negative stereotypes still tend to emerge when disparities in the determinants of health behaviours between Indigenous and non-Indigenous populations are discussed. Such disparities are of major concern in many of the world's well-developed nations, including Australia. Indigenous Australian peoples are largely less healthy, more prone to chronic diseases and have an earlier overall mortality that non-Indigenous people. Compared to non-Indigenous women, Indigenous women are more likely to report their general health as fair or poor, and are only half as likely to assess their health as excellent or very good (Australian Institute of Health and Welfare (AIHW), 2015). These figures are 
concerning, as despite improvements since 1977 and much government investment, Indigenous women continue to report poor health, poor socio-economic situations, and a lower life expectancy by 9.5 years (73.7 years) than non-Indigenous females (83.1 years) (AIHW) 2015, p. 111). As Willis, Reynolds and Keleher (2016, p. 156) claim, these worrying statistics are the consequences of:

dislocation, dispossession and radical changes in living conditions over several generations [which] had a profound physiological and psychological effect on Indigenous peoples, manifesting in many diverse and complex ways: anger, resentment, violence, mental health issues, alcohol abuse, elevated levels of smoking, domestic violence and then heart disease, high blood pressure, and other forms of chronic disease.

It is well known that sport has the capacity to contribute to health and social engagement within Australian society (MacDonald, Abbott, \& Jenkins, 2012). Yet in twenty-first century Australia, Indigenous women report significantly lower rates of participation in sport than all other population groups (Australian Bureau of Statistics (ABS), 2012). ${ }^{1}$

In trying to understand this ongoing challenge, this paper adopts a strengths perspective (Brough, Bond, \& Hunt, 2004; Paraschak \& Thompson, 2014), rather than a focus on deficits, to examine the connection that Indigenous Australian women have with sport. A strengths approach can challenge the contention claimed by Atkinson (1991), Fredericks and others (2002) that modern sport continues to subordinate and marginalise Aboriginal women and girls within a contemporary patriarchal sporting system. A strengths approach aligns with

\footnotetext{
${ }^{1}$ In 2012, ABS figures showed that only $23.3 \%$ of Indigenous women participated in sport or physical activity during the previous 12 months. This compares with participation rates for Indigenous men (37.7\%), nonIndigenous Australian women (66.7\%), and non-Indigenous Australian men (69.8\%). Respondents were asked to describe their participation levels in physical activities for recreation, exercise, or sport.
} 
other recent approaches in sports sociology which place Aboriginal voices at the centre of the research process (see for example Bennie, Apoifis, Marlin and Caron, 2017).

The adoption a strengths-based approach requires us to explore a number of indicators of individual agency and empowerment, and the connections between these and health, wellbeing and human development in Indigenous societies. To do this we draw on data from a range of sources, including interviews and focus groups with Indigenous women living in urban and rural areas (Stronach, Maxwell, \& Taylor, 2015), narratives from elite Indigenous athletes and coaches (Stronach, et al. 2015) and the findings of a recent Australian Parliamentary inquiry into Indigenous health and wellbeing (House of Representatives Standing Committee on Aboriginal and Torres Strait Islander Affairs, 2013; Maxwell, Stronach, Adair, \& Pearce, 2017). A theoretical framework which draws on the work of Emirbayer and Mische (1998) is utilised in the data analysis. Finally, we use the primary data to inform potential health promotion strategies and activities and make recommendations for developing sport management capacities in line with our findings.

\section{Literature Review}

\subsection{Sport Management and Health Promotion}

In 2006, Chalip noted the relative youth of sport management as an academic discipline, and explored the needs and directions for the field's growth and development. Chalip believed that the legitimations that sport advocates were promoting for sport's place on public agendas would be useful starting points for sport focused research. One of these legitimations was health (Chalip, 2006). However, while sport systems throughout the world were increasingly endeavouring to foster elite sport performances (Green \& Oakley, 2001), sports systems were found lacking when endorsing mass sport participation pursuant to health promotion (Chalip, 2006; Murphy \& Waddington, 1998). This, claimed Chalip (2006), was because sport was 
but one form of physical activity. Exercise (e.g. calisthenics, walking), physical recreation (e.g. gardening, dance), and purposive physical activity (e.g. climbing stairs, biking to work) could also provide health benefits, and could do so without engaging sport bureaucracies. Sport, however, had the capacity to provide particular incentives, such as the thrill of competition, the elation of winning, the pleasure of group/team activities, the rewards of captaincy or coaching, and other hedonic rewards that may be absent from mere exercise. However, a significant advantage of sport for pursuing health benefits was that physical and social infrastructures associated with sport clubs and sport programs represent resources that might be leveraged to encourage and enable ongoing exercise and physical activity, provided that sport organisations had incentives of their own, and sport personnel had, or could develop, the requisite skills (Chalip, 2006). The capacity of sport organisations in levering ongoing exercise and physical activity is a key consideration in this discussion.

It seems there are numerous challenges in the capacity of sport organisations to link directly with health issues. For example, Kelly et al (2010) cautioned against the belief that national and state sporting organisations (NSOs and SSOs) in Australia may provide the ideal avenue through which to introduce health-related policies to sports clubs and assist in overcoming barriers related to knowledge and resources. This, they argued, was due to the low availability of health-related policies at peak sporting organisations, indicating that the potential for information transfer to clubs was limited. Furthermore, these authors found that while it appeared that health promotion foundations could provide an important framework for creating health promoting sports clubs (with support from SSOs), further effort and resources were required to operationalise this agenda. In particular, they identified a need to build the capacity of peak organisations to develop health-related policies and to foster partnerships between these organisations and sports clubs for effective communication of policies (Kelly et al., 2010). 
Fast forward a few years and the involvement of key sport organisations in health promotion activities has developed further, but still, it seems, not without challenges. In Australia, researchers continue to focus on upper level sports organisations (NSOs and SSOs), along with key regional organisations, such as government health entities. For example, Casey et al (2012) found that financially well-off SSOs have the capacity to engage in health promotion in a significant way. In fact, these authors reported on 10 Victorian SSOs that had made concerted efforts to create and support sport and exercise contexts that promote healthy behaviours. These included simple strategies such as the distribution of pamphlets providing information on sport programs and healthy eating, through to targeting health inequality groups (e.g., disability, migrant, Indigenous) to encourage sport participation, ensuring sporting environments were healthy and welcoming, and raising awareness of healthy living and sport. Casey et al (2012) claimed that many sport organisations now recognise that, due to their wide reach and informal educational nature, sport activities can and do form a potential setting for health promotion. Similar research in Europe on health promotion at the sports club level demonstrates that sports clubs and/or coaches generally have a positive orientation towards health promotion. However, many have not yet invested in implementation to the same degree; neither at club nor coaching levels (Geidne, Quennerstedt, \& Eriksson, 2013; Kokko, Kannas, \& Villberg, 2009).

Further to the above, recent scholarship suggests that partnerships between public health agencies and non-profit sport organisations still experience constraints in their capacity for collaboration to meet health promotion policy goals (Misener \& Misener, 2016). Effective interaction is critical for increasing sport participation, and ultimately achieving desired health outcomes. There is an obvious requirement for public health agencies (such as educational, health, and social institutions) and sport organisations to work together, rather than in silos, to be able to interact effectively. Moreover, while the values of each partner do 
not necessarily need to be completely mutual or shared, there must be at least a certain degree of complementarity and compatibility, and a recognition of any diverse values. Misener and Misener (2016) found that while sport organisations face considerable pressure to partner with other organisations, many tend to struggle to collaborate effectively, due to limitations related to partnership formation and management, suggesting a misalignment of sport and health partners. Thus, the jury is still out when determining the efficacy of sports organisations in health promotion activities.

\subsection{Sport Promotion and Indigenous Women}

The Ottawa Charter describes health promotion as the process of enabling people to increase control over the determinants of health, thereby improving their health. To reach 'a state of complete physical, mental and social well-being and not merely the absence of disease and infirmity' (World Health Organization, 1948), 'an individual or group must be able to identify and to realize aspiration, to satisfy needs and to change or cope with the environment' (World Health Organization, 1986).

Understanding the factors that may be effective in improving the health of Indigenous Australians is a high priority for individuals, communities and governments. As for all populations, one factor with clear benefits in improving physical health and wellbeing for Indigenous Australians is participation in sport and exercise. Participation increases life expectancy and reduces heart disease, and it is also apparent that sport programs have an important role in improving mental health and wellbeing (Ware \& Meredith, 2013). For example, researchers noted improved mental health and a reduction in self-harming behaviours following Indigenous community sports programs (Frazier, Cappella, \& Atkins, 2007; Sabo, Miller, Melnick, Farrell, \& Barnes, 2005). Specifically, these included reduced suicide and depression in adolescents (Sabo et al. 2005). Participation in sports programs 
may also increase self-esteem, dignity and confidence (House of Representatives Standing Committee on Aboriginal and Torres Strait Islander Affairs (HoRSCATSIA), 2011; Ruhanen \& Whitford, 2011), increased resilience (Hunter, 2012), and pride in one's personal or community achievements (factors said to be crucially important in marginalised communities) (Lonsdale et al., 2011; Tonts, 2005).

When working with Indigenous Australian communities, advocates for Indigenous health contend that programs ought to be culturally appropriate, community controlled, selfdetermining and based on the goals of the community. Programs should also recognise the strengths, assets and capacities of Indigenous peoples (Brough et al., 2004). However, on a cautionary note, Evans et al (2015) warned against the belief that sport participation will necessarily promote Indigenous women's empowerment, or indeed that sport might be considered a panacea for many Indigenous problems, from promoting better health and education outcomes, to encouraging community building. Notwithstanding these views, an increased sense of control or agency and empowerment are major strategies that have been implemented worldwide for alleviating poverty and social exclusion, thereby reducing health disparities (Tsey et al., 2010). Indeed, the Brighton Declaration on Women and Sport is especially relevant to the situation of Indigenous Australian women, for whom the responsibility to family and community is paramount (Stronach et al., 2015):

Sport promotes involvement, integration and responsibility in society and contributes to the development of the community. (WomenSport International, 1994)

\subsection{Historical Context of Indigenous Women and Sport}

The literature gives us some guidance as to the nature of agency for Indigenous women in the past. There is no doubt that with colonisation the experience of sport for Indigenous women changed irrevocably. Before colonisation, sport was a crucial element in the lives of 
Indigenous women. Sport provided competition, fun and recreation in gendered spaces, and gave women special status in communities (Haebich, 2016). As well as cultural and economic importance, sports and games were generally played solely for enjoyment, with victory of minor importance. Participation was high, with many activities of a group nature (Edwards, 2009). Major changes to society after colonisation meant that Indigenous women were stymied from participating in their traditional sports and games, and these all but disappeared (Howell \& Howell, 1992). Sport, once a key component of Aboriginal culture and life, was corrupted and took on new, horrific meanings (Atkinson, 1991). Women's physicality increased their economic value, and for some, this provided a means of survival in the hostile colony. However, women were debased and exploited by white men and often suffered cold-hearted condemnation by white women (Tonkinson, 1988).

In considering why the levels of participation of Indigenous women in sport remain so low, female Indigenous scholars contend that modern sport continues to subordinate and marginalise Aboriginal women and girls because sports within a capitalist society (they claim) have been highly commercialised commodities, dominated by patriarchal images, with women frequently represented as leisure objects and as 'service agents of male recreation desires in the home and outside' (Atkinson, 1991, p. 26).

Indigenous people today are strongly influenced by their precolonial traditions and have resisted tremendous pressures to assimilate. For many years Indigenous women rejected efforts to encourage them into westernised sport, preferring instead concepts of sport, music, dance and craft work that are non-competitive, exciting, creative and culturally acceptable (Fredericks et al, p. 144). It is no wonder, therefore,

... if white women are having difficulty getting to first or second base in sport, then, by comparison, their black sisters are not coming within 'cooee' of the ballpark ... Of all 
such Cinderellas, black women's sport has the strongest case for encouragement, change, and a fair go. (Tatz, 1995, pp. 98-100)

In summary, Indigenous women's involvement in sport and physical activity, from once being an important component of daily life, has reduced to low levels, seemingly due to external factors beyond their control. Arguably, these factors continue to be the effects of colonisation which continue to impede Indigenous women's capacity to be sport and physically active. As Tatz's words emphasise, Indigenous women deserve support to be able to change their current situations as they see fit, thereby taking control of their own health and well-being through sport and exercise programs.

\section{Theoretical framework}

The concept of empowerment is related to terms such as agency, autonomy, self-direction, self-determination, liberation, participation, mobilization and self-confidence. It is a contested term and has been ascribed a wide variety of definitions and meanings in various socio-economic contexts. Empowerment is generally framed as an increase in power, understood as control, or a real ability to effect change (Oakley, 2001). A useful definition of the concept is 'individuals acquiring the power to think and act freely, exercise choice and fulfill their potential' (Mayoux, 2000, p. 49). Once choices are made they can then be transformed into desired actions and outcomes (Mayoux, 2000). Four categorisations of empowerment are: to have power over (ability to resist manipulation), to have power to (creating new possibilities), to have power with (acting in a group) and to have power from within (enhancing self-respect and self-acceptance) (Rowlands, 1997). Empowerment can also increase certain kinds of agency (Alkire, 2005), or put simply, can bring about 'an expansion of agency' (Ibrahim \& Alkire, 2007, p. 9). Empowerment programs seek to 
encourage people to take control of their own lives, adopt healthier lifestyles and use health programs and services more effectively (Tsey \& Haswell-Elkins, 2008).

What then is agency? Webb, Shirato, and Danaher (2002, ix) define it as 'the idea that individuals are equipped with the ability to understand and control their own actions, regardless of the circumstances of their lives'. In other words, individuals have the capacity to take opportunities that come their way, although these may be influenced by the individual's life experiences and social situations. Sen (1985, p. 206) concurs with this notion, defining the concept as 'what a person is free to do and achieve in pursuit of whatever goals or values he or she regards as important'. It follows that agency should be socially beneficial, and that agents (those who act and bring about change) advance goals that people value, and have reason to value (Ibrahim \& Alkire, 2007, p. 9). The processes of agency have clear links to the Rowlands' (1997) categorisations of power, and may involve bargaining and negotiation as well as resistance and manipulation (Ibrahim \& Alkire, 2007). Agency can be experienced with respect to different tasks, such as the ability to help others, make decisions for one's family or a general ability to plan effectively. A lack of agency is often seen as central to ill-being.

Emirbayer and Mische (1998) extended the notions of agency by introducing a temporal element (oriented variously toward the past, future, and present). These authors define agency as:

the temporally constructed engagement by actors of different structural environments - the temporal-relational contexts of action - which, through the interplay of habit, imagination, and judgment, both reproduces and transforms those structures in interactive response to the problems posed by changing historical situations. (p.970) 
According to Emirbayer and Mische (1998), these temporal elements create a chordal triad of agency, within which all three dimensions resonate as 'separate but not always harmonious tones' (p. 971). However, in any given case, one or another of these three aspects might predominate. For example, it is possible to speak of action that is more (or less) engaged with the past, more (or less) directed toward the future, and more (or less) responsive to the present. In this article, agency will be ascribed to the three different dimensions. A caveat to this is that knowledge relating to action engaged with the past will derive primarily from the literature. In temporal terms we have considered the time frames to be defined by generational change. Thus the present is generally represented by activities during the participant's lifetime.

Utilising the theoretical concepts outlined above, this research examines the following questions:

- What is the role of Indigenous women's agency in their sport experiences?

- How can Indigenous women's agency developed through sport contribute to improvements in their own health and wellbeing, and that of their families and communities?

- How do sports programs contribute to Indigenous women's capacity to develop agency?

\section{Method}

The research used three distinct populations: Indigenous Australian women in urban and rural communities, elite female Indigenous athletes and coaches, and those interested individuals and organisations who provided submissions to the House of Representatives Standing Committee on Aboriginal and Torres Strait Islander Affairs Inquiry (2013). The research design adopted the principles of content analysis (Berg, 2007) for the Inquiry submissions, and an inductive interpretive approach for the focus group and individual interviews. This 
research design created a triangulation of data sources to study the phenomena. Before data collection, Ethics approval was obtained from the UTS Ethics Committee (UTS HREC REF No. ETH16-0873).

\subsection{Participants}

Participants in the individual interviews and focus groups ranged from 18 years to 72 years of age and were from urban and rural locations. They derived from the female Indigenous populations of two Australian locations, Sydney, New South Wales and Flinders Island, Tasmania, two areas with very different population demographics. Researchers made contact with the Flinders Island Aboriginal Association Inc. (FIAAI), and in NSW, the Mudgin-Gal Women's Group, Redfern, the National Centre for Indigenous Excellence (NCIE), Redfern, and Tranby Indigenous College, Glebe. Individuals at those organisations circulated invitations to local Indigenous women to participate in the research. The 22 women who accepted met with researchers at the organisations' premises. A further three Indigenous women who were elite athletes, as well as three who were currently coaching sport at community or elite levels — or had done so in the past—participated in individual interviews.

\subsection{Indigenous methodology: Dadirri}

Any investigation of the role of sport in the lives of Indigenous women needs to be contextual, nuanced, and approached with great sensitivity. Responding to these concerns, the research team in this project committed to a methodology known as Dadirri. The methodology provided an appropriate pathway for the team to follow in their quest to appreciate how and why Indigenous women function in their own cultures and environments. In recent years, researchers have employed Dadirri in research with Indigenous people, particularly where complex cultural and personal issues have needed investigation (see for 
examples, Atkinson, 2000; Stronach \& Adair, 2014). Indigenous scholar Professor Judy Atkinson explains the concept this way:

[Dadirri brings] a knowledge and consideration of community and the diversity and unique nature that each individual brings to community; ways of relating and acting within community; a non-intrusive observation, or quietly aware watching; a deep listening and hearing with more than the ears; a reflective non-judgmental consideration of what is being seen and heard; and, having learnt from the listening, a purposeful plan to act, with actions informed by learning wisdom and the informed responsibility that comes with knowledge. (Atkinson, 2000, p. 16)

Dadirri is not a research methodology in the Western scientific tradition, but proceeds inductively by gathering information through quiet observation and deep listening, building knowledge through sensitivity and awareness, and developing understanding by contemplation and reflection (Atkinson, 2000). Dadirri may operate at many levels, especially where there is a search for profound understanding, and to this end the concept suggests 'more than just listening by the ear, but listening from the heart' (Atkinson 2000, p. 19), suggesting a depth of critical thinking and intensity of feeling. Dadirri's approach to research has the following associations with Western methods and methodologies:

- Consciousness-raising: where a raised consciousness between the researcher and the researched gives value to community processes.

- Participatory action: recognition of the valuable contribution people make in their activities of relating, defining, and narrating their life experiences.

- Reciprocity: ethical research from within an Indigenous worldview and critical pedagogy must be embedded with reciprocity_receiving something and giving something. 
- Phenomenology: utilising a narrative approach enables the understanding between the inner world of an individual and the outer world (Atkinson 2000).

\subsection{Interview Protocols}

Both focus group and individual interviewees were given the opportunity to express their opinions through conversations either individually or as part of a group of like-minded people. The conversation approach is a loose, fluid, and flexible invitation to share information by personal narratives or story-telling. Given the strong oral and story-telling traditions of Indigenous peoples, and, indeed the empowerment potential of story-telling (Williams, Labonte, \& O'Brien, 2003), researchers considered a strategy to allow the women to provide information using a narrative style and face-to-face engagement most appropriate, and certainly more effective than standard question and answer sessions (Ralph, 1997). This approach has the potential to uncover, from an inside perspective, a broad range of topics, including the women's experiences and their perceived values of sport, as well as barriers and enablers to agency and sport participation. In both the focus group and individual interviews, women considered their present situations and how these might have been influenced by past experiences. Researchers helped stimulate discussion and urged participants to speak freely about their thoughts and ideas, and in particular, to visualise how they could enhance their agency and empowerment in the future. Finally, pseudonyms were assigned to participants to provide an ethically sound yet personal and intimate presentation of the data.

\subsection{Researcher Qualities}

As is appropriate with research involving Indigenous people, one researcher in this project is an Indigenous Australian woman, from the Gooreng Gooreng nation of Queensland. The other two researchers, although non-Indigenous women, have relevant experience; one has 
worked with Indigenous men, and the other has worked with culturally and linguistically diverse groups of women. The research team has worked collaboratively in earlier projects.

\subsection{Data Analysis}

Both focus group and individual interviews were tape-recorded, transcribed and spot checked for accuracy. The transcripts were then analyzed with Nvivo (v9). To create the typological analysis researchers first read transcripts for keywords, phrases and concepts, at the same time creating categories or groups on 'the basis of some canon for disaggregating a whole phenomenon' (Howe \& Brainerd, 1988, p. 201). The transcripts were electronically coded and textually analysed. The research team then used constant comparison to look for similarities or differences (Miles \& Huberman, 1994).

Initial coding involved identification of emergent themes arising from the temporalrelational model of agency (Emirbayer \& Mische, 1998), that is, agency engaged with the past, agency directed toward the future, and agency responsive to the present. The caveat to this, as already mentioned, is that knowledge relating to agency engaged with the past has derived primarily from the literature.

A qualitative content analysis was undertaken of the 58 submissions (1366 pages) presented as formal evidence to House of Representatives Standing Committee on Aboriginal and Torres Strait Islander Affairs. The texts were received by the parliamentary committee on behalf of Indigenous representatives, sport organisations, community agencies, academics and social workers. Content analysis allowed researchers to identify, and analyse occurrences of specific messages and message characteristics embedded in texts.

After merging the three data sets, a thematic analysis of the merged data sets followed, as researchers considered what was seen, read and heard. Finally, the three researchers 
conducted a cross-examination to ensure that the themes were representative of the transcripts and submissions and were culturally accurate. Figure 1 provides a conceptualisation of the data analysis process.

\section{[Insert Figure 1 here]}

\section{Findings}

After the analysis of the focus groups and individual interview transcripts, as well as the content analysis of the 58 submissions, 11 themes emerged for the two temporal-relational elements of agency. There were substantial links between and across themes, which are illustrated in Table 1.

\section{[Insert Table 1 here]}

\subsection{Indigenous women and sport today}

When considering the present, this study uses the iterational element of agency, or agency that is responsive to the present.

\subsubsection{Building communities}

Stories of highly sport active younger lives were common amongst the women interviewed, whether they were from urban or rural backgrounds. Many had very positive attitudes towards sport participation and suggested that sport is integral to developing and connecting family and community. Consequently, the women regarded sport highly, and clearly, they felt that sport offers opportunities for developing agency. For example:

When I was in foster care I did Little Athletics, Little Athletics and Girl's Brigade.

Girl's Brigade back then was quite big, we did, say, cross country and swimming carnivals and athletics. I also did netball. Then I did netball from grade three all the 
way. Then I ended up managing a netball club ... and convening the umpiring. (Joy, 43, Sydney, coach)

Cynthia (58, Sydney, Focus Group) concurred, commenting:

It's (sport is) very, very important. It brings you together. It builds a network. It builds a community network and all your support system. It did for me and my kids and my grandies. It's healthy too!

Women in rural areas demonstrated the significance of sport in their communities:

It's part of a social event. When we play netball, we are very competitive. We have a rivalry and we cheer each other on. Social side like the end of season events, the prizes and trophies they give out. Cousins play together and are encouraged to play, coach kids and turn up every week! (Kirra, 57, Flinders Island, Focus Group)

Sporting activities like community fun runs, sports carnivals and competitions bring communities together - an imperative for Indigenous women. The NSW Rugby League Knockout is an excellent example, as Allira (42, Sydney) explained:

There's the rugby league knockout, the Koori knockout ... about 10,000 people go to it ... it's kind of took over the whole corroboree thing ... it's more just a modern way of getting together, bringing Aboriginal communities together, different families and different groups of families and groups of Aboriginal people, the clan all coming together.

However, as well as enjoyment, the women indicated that Indigenous control of sporting activities was essential, including, for example, the delivery of programs in traditional languages (House of Representatives Standing Committe on Aboriginal and Torres Strait Islander Affairs, 2013, \# 33 Hockey Queensland Inc). Jill (Flinders Island, 50, Focus Group) 
described how members of her group have ensured Indigenous control of their sporting activities:

We encourage each other to play to turn up every week, we had a $99 \%$ Aboriginal team, six Aboriginal players and one non-aboriginal player, we had an elder coaching the netball team.

Through sport, women develop distinct identities as enablers for their families. However, this enabling role may sometimes be at the expense of women's own participation, as Joy (43, Sydney, coach) explained:

I think it's ironic that you get men, like, you know, they decide to go surfing, like my brothers, and they go driving off to the beach and everything, even though they had families and kids. But I love surfing but I couldn't do that because I have a kid and I have to work full time and look after the kid and look after the house.

The outcome of building communities is that Indigenous women may become empowered to create new opportunities.

\subsubsection{Team building}

Sport today offers Indigenous women a social meeting place, a means of participating in activities that are culturally appropriate, and a way to maintain culture. Darri (38, Sydney) explained:

I guess it's like sport's a part of culture in a lot of Aboriginal communities ... it's a rugby league culture around here. Even now, as a mother [with] my daughter, you know, mucking around with her with a ball and stuff like that and trying to teach her how to catch and kick a ball. 
Ruth (35, Sydney, Focus Group) was excited when she described how just being together and being active with other Indigenous women was so important for women:

I am so excited, especially that we've all been able to come together on our own, just us girls and bond together and noticing that real strength in the women coming out ... it's really empowering to have us all together and seeing that strength in each other and encouraging each other and encouraging that encouragement ... Yeah, complete sisterhood. (Ruth, 35, Sydney, Focus Group)

As one of the most socially disadvantaged groups in Australia (Van Acker, 1999), such a sisterhood (in Ruth's words) of Indigenous women is based on shared understandings, and common experiences, perceptions, values and goals. Being part of a group or team helps women to develop agency and ultimately empowers them.

\subsubsection{Partnerships}

Like team building, creating partnerships is a situation wherein women can become empowered through working with others. A number of cases clearly demonstrated Indigenous women developing agency by taking ownership and leadership roles in sports programs and associated activities, provided that they are given opportunities and support. For example, the Onkaparinga Women's Rugby Club, Softball Australia, Hockey Queensland, the David Wirrpunda Foundation (The Deadly Sistas Girlz Program, Gwabba Yorga-Gabba Worra, and the Moorditj Mums) and VicHealth were cited in the 2013 Parliamentary Inquiry as directed programs which boost assertive action and empower Indigenous women. These key examples (see below, Table 2) show the importance of organisations working through health promotion partnerships to facilitate the development of Indigenous women's agency and empowerment through sport.

[Insert Table 2 here] 
Significantly, not all these programs involve organised sport. Women like Flinders Island resident, Kirra (57, Focus Group), recognised the importance of exercise for women, but did not feel that this necessarily meant competition. She wanted:

to see a specific group for women-Aboriginal women. Walking on Flinders is a bigger activity as women go collecting shells, mutton birding and fishing ... I myself started a walking group on Sundays to try and get us girls together ... for the social aspect plus the fitness.

In another example of constructive partnerships, in this case, the local community sport association had teamed with the Aboriginal Association to provide resources and support for Kirra's efforts to enable an ongoing exercise program for her group, where competition was of little relevance.

\subsubsection{Discrimination and racism}

Interviewees described some situations where they needed to develop power to resist negativity and manipulation. One of these was racism. Even in their own lifetimes, members of the participation group had encountered racist attitudes resulting in discrimination. One older woman (Lorraine, 72, Sydney, Focus Group) had lived at Moree during a particularly unpleasant period in Australian history during the 1950s, wherein the banning from swimming pools was a reality for Indigenous people. ${ }^{2}$ She related her experiences: You could never be a swimmer. You could never learn to swim or swim in an Olympic pool because in the sixties you weren't allowed to do that. You were told that Aboriginal people weren't allowed in there [... Then all of a sudden, the mission got a

\footnotetext{
${ }^{2}$ For an analysis of this situation see Adair and Stronach (2014).
} 
35 metre pool [but] the only time we were allowed in that pool was for the school swimming carnivals.

It appears that discrimination based on skin colour still pervades Indigenous women's involvement in sport and this was considered a disempowering factor and a significant impediment for the development of Indigenous women's agency through sport.

\subsubsection{Shame}

Two women who had close ties with swimming highlighted another complex matter. This revolved around poor self-esteem, which seemed to link with the concept of shame (Louth, 2016). The notion of shame is a little unclear as it has different connotations for nonIndigenous than for Indigenous people, for whom the meaning of shame extends to include embarrassment in particular instances (Leitner \& Malcolm, 2007). Sometimes unwarranted or uninvited attention or circumstances rather than as the result of an action by oneself can cause shame (Vallance \& Tchacos, 2001). Indeed, shame may completely engulf and disempower an Indigenous person.

Lorraine and Kathy, two women separated by a 50-year age gap, found that participating in sport caused them acute shame, which undermined their self-confidence and self-esteem, and detracted from their ability to develop agency through their sporting activities. Lorraine (72, Sydney, Focus Group) recounted:

Any little thing that you did different or wrong it gives them another reason to have a go at you ... I'll never forget one time I did the [swimming lessons]. I started in the kids' class, I was in the babies' pool. I didn't have proper swimmers. Mum couldn't afford it. You had to sit on the edge of the babies' pool and put your feet there and push out and go to the wall. Naturally my pants fell down because they weren't proper swimmers and you just go [pulls a face] so of course I didn't go back to that class. 
The younger Kathy (20, Sydney, elite athlete) remembered feeling embarrassed and awkward when plying sport at school. It seemed this was because she was targeted for being different, not only for being Indigenous but also because of her sporting prowess:

I was the only Aboriginal. In primary it was me and my brother and so you're under the spotlight anyway. Then I went to high school and I was the only Aboriginal person in my high school. You're getting targeted for any little thing. I often wonder if I wasn't good at [sport] if things had have been different because you're allowed to come and play but you're not allowed to win.

This notion of shame is another disempowering factor and an obstacle to Indigenous women developing agency through sport. To combat these feelings, Indigenous women need to develop power from within to be able to enhance self-respect and self-acceptance.

\subsubsection{Gaining strength}

Despite the hurt that must result from incidents such as those outlined above, some women were able to turn them into opportunities for growth and at the same time to foster agency. Indeed, many were able to find an inner power to counteract negative situations and resist manipulation. One example was given by Glenda (29, Sydney), who recalled a time when she was unable to buy a particular pair of sports shoes:

I had a non-Indigenous person say, "When you can afford to buy these shoes", blah, blah, but I've learnt from that and I can be more stronger with that person now. You know what I mean? Little things like that make me strong, some people's negative attitudes. You know what I mean?

Erica (24, Sydney) described an under-privileged younger life. She could have succumbed to adverse social pressures, but, like Glenda, demonstrated the power to resist and ultimately achieve her sporting goals: 
I guess my parents, they never got taught a lot of things, so they could teach me a lot of things and not by any fault of theirs or anybody else's, that's just the way life is, but um, I've had to try and find that confidence in myself or from other ways or in life somehow and to really step out and take that risk to want to go for those goals.

The ability of Indigenous women to develop strength through sporting accomplishmentsindeed their resilience against adversity—enables them to develop greater self-confidence and resist negative stereotypes.

\subsubsection{Affordability}

A key concern and a major obstacle for involvement in sport was the cost of accessing sports programs. Indeed, participants described the cost of taking part in sport as the most pressing barrier to their current participation. Comments such as 'it's really expensive' and 'for people who don't have the means it sort of holds them back' (Joy, 43, Sydney, coach) were heard frequently from women from urban or rural areas alike. Joy elaborated 'I had to hock my surfboard to pay the milk fees when my son was little. That was the last of my surfboards. I haven't surfed since'. Cost is an even greater barrier to participation in the more affluent sports, as Hanya (60, Sydney, Focus Group) explained:

[We should be] encouraged to play all different sports because, for example, we've only ever had that one tennis player; that was many many years ago, and she became a champion. I haven't even heard of a golf player or a sport that we would consider rich sport.

Indigenous women need support, including financial assistance, to empower them to create their own new sporting possibilities.

\subsection{Indigenous women and sport in the future}


When considering the future, this study uses the projective element of agency, or agency directed toward the future.

\subsubsection{Loving to lead}

Indigenous women suggested that they can and will continue to take control of their sport engagement (whenever and wherever possible). The women discussed their desires to continue participating in sport and exercise and increase their involvement if supported to do so. Anna (24, Sydney, elite athlete) was keen to encourage other women to become active, stating, 'I think we've all got the ability and, see I'm not all about being good, I just want people to do it, but to do it, you've just got to do it!' The women wanted to grasp opportunities that came their way. Helen (44, Sydney, Focus Group) articulated this:

My parents, they tell me about how mad they were when they were younger and all the things that they did, you know. It's like, like, it would be great just to see them doing that, you know, and it would be great to still see that within the Indigenous community. Because from what I can see it's like that the majority of Indigenous people just, like me, have a love for sport or a passion for sport and it would be great to see that, like, just keep going.

Women in both urban and rural locations spoke about the kind of physical activities they would like to see for older Indigenous women. Once again competition and organised sport were not necessarily key requirements for this cohort:

I'd like to see more over 50s exercise groups. But I'm talking about exercise that doesn't feel like exercise ... like, you know, very slow pace pedaling or paddling. But nice activities for the over 50s to just, yeah, do and slowly get fitter. (Joy, 43, Sydney, coach) 
On Flinders Island Leura (55, coach) discussed how she wanted to support people in her community to achieve their fitness goals:

One of my plans is if I lose a bit more weight and that is to be a personal trainer, even though at my age, 52, but to also to exercise with the elderly ... I'd like to do that. Walking, like power walking and orienteering and stuff like that. Yeah.

The comments here demonstrate that through sport, these Indigenous women are empowered to lead, and this enhances their self-respect and self-acceptance.

\subsubsection{Role models}

The value of female sporting role models to increase women's participation in sports programs is well-known (see for examples, Adriaanse \& Crosswhite, 2008; Meier, 2015). These might be family members, peers or other sports people. However, women interviewed for this study felt that female Indigenous role models were few and far between. These women were concerned about this situation and wanted to see more Indigenous female role models. They felt this would help to engage and encourage girls to participate and be sport active. Ruby (35, Sydney, elite athlete) was only too aware of what was needed:

Well, I suppose we need more women role models in sport. Like Cathy Freeman, Nova Peris, they're probably the main Indigenous role models that we have. You see heaps of guy role models these days and you don't really see female role models, especially in the Indigenous community. So females don't have anyone to look up to, to get motivated and to do a sport.

However, the women could not articulate how this might happen, thus demonstrating that this was an area where empowerment may enable them to create new options in the sporting arena.

\subsubsection{Cultural safety}


Many participants saw the notion of a safe space within which to be physically active as highly significant, as these spaces gave women the opportunity to exercise their inner power and enhance self-respect and self-acceptance. Lorraine (72, Sydney, Focus Group) explained the local Indigenous sports centre was, 'a safe space for them to come; it's an Aboriginal organisation. It's run by Aboriginal people'. However, Joy (43, Sydney, coach) pulled no punches, declaring that for her, a gym is not culturally safe:

I don't want to go to a gym and be in my tracky dacs and my singlet while I've got all these skinny size eights and everything around me ... to me it's not a safe place, a gym.

Women also attested to the value of Indigenous women-only sporting activities offered by local Indigenous organisations. They expressed a desire to continue or to increase their involvement in this type of activity in the future:

There's a lot of pleasure and passion in it and there's a lot of outcomes for you. It's a healthy outcome. That's what I sort of felt what I was bringing to my sport was that I was teaching my children, you know, about wellbeing, about activities. Even now, and I'm thinking, 'Well, what sport am I going to get her into when she gets big?' (Darri, 38, Sydney)

Cultural safety, particularly in safe spaces, empowers Indigenous women and allows their self-respect and self-acceptance to be enhanced.

\subsubsection{Policies and support}

Hanya (60, Sydney, Focus Group) discussed how she believed Indigenous women could contribute in policy-making spheres empowered to manage their own needs:

Unless there's a concerted specific policy which supports that and there's infrastructure around it there seems to be very little which supports Aboriginal women to do things. 
... So that's involving the women in developing a program for themselves as well and then that gives it strength.

Inclusion of Indigenous women in policy making around their own sporting needs empowers them to create new opportunities for themselves and their communities.

\section{Discussion}

\subsection{The role of Indigenous women's agency in their sport experiences}

Our findings build on national and international evidence which show that interventions which empower socially excluded groups can be linked to health outcomes and quality of life (see for example, Tsey and Haswell-Elkins 2008). The concept of agency (Sen 1985, Ibrahim and Alkire 2007) resonates powerfully with Indigenous Australian women's desires to be self-determining. In Australia, a lack of agency has long been one aspect of a broader experience of powerlessness. Addressing this issue may reduce the current preventable Indigenous burden of disease and close the health disparity gap (Tsey et al. 2010).

Findings indicate that empowerment through participation in sport provides an opportunity for Indigenous women to improve their self-esteem by gaining strength and confidence, overcome feelings of shame and to resist manipulation and discrimination. This clearly resonates with Rowlands' (1997) idea of having power over. These opportunities may enable Indigenous women to reconnect with their historical love of sport activities. Sport was common pre-colonisation, and occurred in gendered spaces, which in some instances lead to the special status of women in their communities (Haebich 2016). As Indigenous women develop agency through sport they may also improve not only their own physical and mental health and wellbeing, but also that of their families and wider communities.

When Indigenous women are empowered to participate their self-respect and self-acceptance may be enhanced. This may occur when sports programs acknowledge the strengths, assets 
and capacities of Indigenous peoples (Brough, Bond, and Hunt 2004). Marcia Ella-Duncan, an elite Indigenous netball coach, reflects on this notion:

I loved leading and being part of a group of Aboriginal women. My experience is ... when you're an Aboriginal athlete you are naturally volunteering your time to your community ... in the process we not only deepen our understanding of the game, we deepen our understanding of ourselves because we're constantly challenging ourselves about how we can be better and how we can encourage our players to be better, we're developing know how about how to draw the best out of people and resilience and problem solving (Ella-Duncan 2016).

A focus on agency and empowerment through team work, community building, leadership, partnership, safe environments (all key characteristics of our findings) aligns with recent research recommendations from sport for development and peace research in Australia and North America (Hayhurst, Giles, \& Wright, 2016). Hayhurst et al (2016) found that sporting programs need to be designed and delivered through a foundation of Indigenous knowledge, beliefs and practices, so that women can be supported to challenge racist and sexist stereotypes about their communities, which occur all too often in the wider Australian society. Lavallée (2008) as well as Wilson and Yellow Bird (2005), underscore this concept and remind us that health promotion and physical activity programs are utilised by Indigenous populations in many countries to reduce the on-going effects of colonisation.

\subsection{The contribution of agency developed through sport to improvements in Indigenous women's health and wellbeing, and that of their families and communities.}

Findings indicate that empowerment through working together as a group, leading others and promoting role models can be positive factors in improving Indigenous women's health and wellbeing, as well as that of their families and societies. Aboriginal people in leadership roles 
in sport, such as acting as role models and mentors for others, were critical enabling factors in Bennie and colleagues' recent research (2017), which, they argued, could boost confidence within Aboriginal communities and positively influence some of the preconceived stereotypes about Aboriginal deficits.

We contend that Indigenous women's agency in respect to participation in sport in the past was, and in many cases still is, stifled because of their grim history, racism and ongoing links with the past. It seems that the legacy of such incidents is that some Indigenous women still avoid sport and lack confidence in others. Therefore Indigenous women may continue to lag behind non-Indigenous women in terms of sport participation. These patterns of thought and action can be characterised as resistance, with the result that 'we limit our potential—which is an impact of colonisation' (Ella-Duncan 2016). Such a sensitive issue needs to be understood both by health policy makers and sport managers alike.

Findings indicate found that discrimination and racism in sport were still experienced by the current cohort. Consequently, people working in the sports industry at all levels need to develop understanding and empathy. Strategies may include cultural awareness programs at sport club and organisation levels. People working with Indigenous people in post-colonial societies such as Australia need to be mindful that some Indigenous people are still experiencing trans-generational grief and loss, due to racism, negative community attitudes and discriminatory practices (Tsey et al., 2010).

\subsection{The contribution of sport to Indigenous women's capacity to develop agency.}

Partnerships between established national, state and local sporting organisations, health promotion organisations and Indigenous organisations leading to the development of appropriate sporting programs for Indigenous women show signs of success. As detailed in Table 2, there are some significant and appropriate exemplars such as the Onkaparinga 
Women's Rugby Club, Softball Australia, Hockey Queensland, and David Wirrpunda Foundation (Maxwell et al, 2017), all of which demonstrate innovation and creativity. Another successful partnership is that between Softball Australia and the Indigenous organisation Red Dust to deliver the Indigenous Softball Program to 7,800 Indigenous participants in the Northern Territory. Long-term partnerships which combine micro and macro policies and programs can facilitate health gain (C. Willis, Greene, Abramowicz, \& Riley, 2016), a factor supported by other Indigenous Australian health researchers (see for example Tsey et al. 2010).

Findings indicate that Indigenous women take comfort and draw strength from safe spaces, which is not surprising given the common experiences of racism and discrimination they described. Sporting programs that provide safe spaces for Indigenous people can 'diminish the presence and effect of lateral violence and to enhance the habits of respect' (Bulman and Hayes 2011, p. 21). In the 2013 Parliamentary Inquiry submissions, cultural safety also emerged as a key theme and there were further examples of sport providers attempting to provide culturally appropriate activities such as sports carnivals and gala days (House of Representatives Standing Committee on Aboriginal and Torres Strait Islander Affairs 2013, Submission \# 44 Ms Heidi Norman).

Findings also suggest that a further critical component of future sports programs is affordability. The lack of funding discussed by participants seems to be occurring at a time when, according to authors such as Casey et al (2012), financially well-off SSOs have the capacity to engage in health promotion in a significant way. Overall the Indigenous women wanted involvement in sport program design to reflect their unique strengths, assets and community requirements, and with support, are keen to be influential in program design.

\section{Implications for policy and practice}


Policy-makers need to understand the role of Indigenous women in sport and the development of agency in the context of Indigenous culture, family networks, gender norms, and history, so as to inform health promotion policy and sport management practice. At a time when Indigenous families in Australia may be looked at pathologically (i.e. domestic violence, alcoholism, sexual abuse), a focus on women as empowering agents is welcome. Without specific policies and support at sport club or organisation level, Aboriginal women may continue to miss out. Therefore, women need support to develop agency and become empowered to access available support and certainly to influence policy.

From a policy perspective this research concurs with Kelly and colleagues (2010). These authors point out that NSOs and SSOs in Australia can provide an opportunity to introduce health-related policies to sports clubs and assist in overcoming barriers related to knowledge and resources. However, the low availability of health-related policies at peak sporting organisations indicates that the potential for information transfer to clubs is currently limited, as is the impact on targeted populations.

Nevertheless, health promotion foundations could provide an important framework for creating health promoting sports clubs. Clearly, further effort and resources are required to operationalise this agenda. Kelly et al (2010) point out the need to build the capacity of Australian peak sporting organisations to develop health-related policies and to foster partnerships between Indigenous and health organisations and sports clubs for effective delivery of health policies. Such capacity building could involve increasing the employment of female Indigenous sport development officers across a wider range of sporting contexts. Sport managers and administrators should recognise that sport for Indigenous women is not detached from other spheres of life. Therefore programs and policies promoting sport should be incorporated into holistic approaches to developing health and well-being objectives. For 
example, the projects delivered through the David Wirrpunda Foundation involve positive female Indigenous role models, personal mentoring for girls, positive social interaction through sporting activities combined with an asset-based approach linked to good communication and self-discipline. Some health messages addressed social problems such as binge drinking and/or developing safe communities.

These policy strategies are not only about sport, or only about health, as much of the evidence points to regular exercise promoting health, and in the company of other Indigenous women in order to create a sense of wellbeing. All this is dependent, of course, on programs, policies and practices that are designed to include and engage Indigenous women in the type of activities that they feel are appropriate, regardless of whether they involve organised, competitive sport. Programs developed by Vic Health through the Fitzroy Stars Football and Netball Club that promote healthy living, fitness, nutrition and self-esteem are good exemplars of the type of programs that appeal to Indigenous women, and help to develop agency. Sport managers need to embrace the different and unique attributes that Indigenous women can bring to sport and exercise and encourage the potential of Indigenous women as leaders in playing, coaching and managing roles.

The voices of Indigenous women in these research findings are critical in informing sports policy, programs and practices which aim to enhance 'a state of complete physical, mental and social well-being and not merely the absence of disease and infirmity' (World Health Organization, 1948). It is disappointing that even in the 2013 Parliamentary Inquiry discussed in this paper, the voices of Indigenous women were largely absent from the submissions (Maxwell et al, 2017). Bennie and colleagues (2017) also note that sporting organisations fail to attract female Indigenous coaches across a range of sports and that most available research about Aboriginal peoples has to date focused on male sports. Yet the participants in this study firmly expressed the desire to have an equal voice in the determination of contemporary 
policies and programs to properly express Indigenous traditions and cultural values. Participants expressed a need for dedicated, safe, culturally appropriate, family-friendly, community-based opportunities to participate in sport in an environment lead by other Indigenous women.

As the 2013 Parliamentary Inquiry demonstrates, a small number of sport providers are starting to implement such strategies to facilitate the participation of Indigenous women. The challenge remains to understand better how sport programs are most likely to overcome gender, financial and other barriers to meet and facilitate the needs, strengths and aspirations of Indigenous Australian women.

\section{Conclusion}

This research makes recommendations about how sports could be managed to promote the health of Indigenous women which are relevant not only in an Australia context but also in a wider international context in postcolonial settings such as the United States, Canada and New Zealand. Recommendations emerged from conversations with Indigenous women, in which their voices were privileged. We contend that without considering Indigenous women's perspectives of sport and exercise development and management for improving health outcomes, health promotion initiatives are likely to be ineffective. Listening to the Indigenous women, modifying sport and exercise offerings where appropriate and empowering the women to help themselves will all work to help women reap the benefits of sporting and health programs and opportunities. Empowering Indigenous women will help to develop role models who can lead other women in their communities to gain the health benefits that regular sport and exercise can offer.

In summary, a strengths-based analysis of the experiences of Indigenous Australian women in sporting contexts provides useful insights into appropriate health promotion practices for 
this cohort. Developing agency will help women to become empowered to self-manage their health concerns. This is very relevant considering health disparities between Indigenous and non-Indigenous Australians and the positive impacts sport can have on health and well-being (Tatz and Adair, 2009). Key to moving forward will be the development of an assets-based approach with Indigenous women working closely with health agencies and sport organisations. 


\section{REFERENCE LIST}

Adair, D., \& Stronach, M. (2014). Kwementyaye (Charles) Perkins: Indigenous Soccer Player and Australian Political Activist. The International Journal of the History of Sport, 31(7), 78-794.

Adriaanse, J., \& Crosswhite, J. (2008). 'David or Mia? The influence of gender on adolescent girls' choice of sport role models. Women's Studies International Forum, 3(5), 383-389.

Alkire, S. (2005). Subjective quantitative studies of human agency. Social Indicators Research, 74(1), 217-260.

Atkinson, J. (1991). Recreation in the Aboriginal Community. Canberra.

Atkinson, J. (2000). Trauma Trails, Recreating Song Lines. The Transgenerational Effects of Trauma in Indigenous Australia. Melbourne: Spinifex Press.

Australian Bureau of Statistics (ABS). (2012). '4177.0 - Participation in Sport and Physical Recreation, Australia, 2011-12.

Australian Institute of Health and Welfare (AIHW). (2015). The health and welfare of Australia's Aboriginal and Torres Strait Islander peoples Cat. No. IHW 147. Canberra: AlHW.

Berg, B. L. (2007). Qualitative Research Methods for the Social Sciences 6th Edn. Boston: Pearson.

Brough, M., Bond, C., \& Hunt, J. (2004). Strong in the City: toward a strength-based approach in Indigenous health promotion. Health Promotion Journal of Australia, 15, 215-220.

Casey, M., Payne, W., \& Eime, R., et al. (2012). Organisational readiness and capacity building strategies of sporting organisations to promote health. Sport Management Review, 15(1), 109-124.

Chalip, L. (2006). Toward a Distinctive Sport Management Discipline. Journal of Sport Management, 20(1), 1-21.

Edwards, K. (2009). Traditional games of a timeless land: Play cultures in Aboriginal and Torres Strait Islander communities. Australian Aboriginal Studies, 2, 32-44.

Emirbayer, M., \& Mische, A. (1998). What Is Agency? American Journal of Sociology, 103(4), 9621023.

Evans, J., Wilson, R., Dalton, B., \& Georgakis, S. (2015). Indigenous Participation in Australian Sport: The Perils of the 'Panacea' Proposition. Cosmopolitan Civil Societies Journal, 7(1).

Frazier, S., Cappella, E., \& Atkins, M. (2007). Linking mental health and after school systems for children in urban poverty: preventing problems, promoting possibilities. Administration and Policy in Mental Health and Mental Health Services Research, 34(4), 389-399.

Geidne, S., Quennerstedt, M., \& Eriksson, C. (2013). The youth sports club as a health-promoting setting: an integrative review of research. Scandinavian Journal of Public Health, 41, 269283.

Green, M., \& Oakley, B. (2001). Lesson-drawing: International perspectives on elite sport development systems in established nations. Paper presented at the Nation and Sport Conference, Brunel University, UK.

Haebich, A. (2016). Aboriginal Women The Encyclopedia of Women \& Leadership in TwentiethCentury Australia.

Hayhurst, L., Giles, A., \& Wright, J. (2016). Biopedagogies and Indigenous knowledge: examining sport for development and peace for urban Indigenous young women in Canada and Australia. Sport, Education and Society, 21(4), 549-569.

House of Representatives Standing Committe on Aboriginal and Torres Strait Islander Affairs. (2013). Sport - More Than Just a Game. Retrieved from Canberra:

House of Representatives Standing Committee on Aboriginal and Torres Strait Islander Affairs. (2013). Sport-More Than Just a Game: Contribution of sport to Indigenous wellbeing and mentoring. Retrieved from Canberra:

Howe, M., \& Brainerd, C. (1988). Cognitive development in adulthood: progress in cognitive development research. New York: Springer-Verlag. 
Howell, R. A., \& Howell, M. (1992). The Genesis of Sport in Queensland: From the Dreamtime to Federation. St Lucia.

Hunter, C. (2012). Is resilience still a useful concept when working with children and young people? CFCA Paper No. 2. Melbourne: Australian Institute of Family Studies.

Ibrahim, S., \& Alkire, S. (2007). Agency \& Empowerment: 'A proposal for internationally comparable indicators: OPHI Working Paper Series.

Kelly, B., Baur, L., Bauman, A., Smith, B., Saleh, S., King, L., \& Chapman, K. (2010). Health promotion in sport: An analysis of peak sporting organisations' health policies. Journal of Science and Medicine in Sport, 13(6), 566-567.

Kokko, S., Kannas, L., \& Villberg, J. (2009). Health promotion profile of youth sports clubs: club officials' and coaches' perceptions. Health Promotion International, 24, 26-35.

Lavallée, L. (2008). Balancing the medicine wheel through physical activity. Journal of Aboriginal Health, 4(1), 1-29.

Leitner, G., \& Malcolm, I. (2007). The habitat of Australia's aboriginal languages: past, present and future. Berlin: De Gruyter Mouton

Lonsdale, M., Wilkinson, J., Armstrong, S., McClay, D., Clerke, S., Cook, J., \& et al. (2011). Evaluation of the Sporting Chance Program, Prepared for the Australian Government Department of Education, Employment and Workplace Relations. Melbourne: Australian Council for Educational Research.

Louth, S. (2016). Overcoming the "shame" factor: Empowering Indigenous People to Share and Celebrate Their Culture. Paper presented at the 2012 International Conference: Innovative Research in a Changing and Challenging World, 16-18 May 2012, Phuket, Thailand. https://eprints.usq.edu.au/23010/1/overcoming_the_shame_factor.louth.s.pdf

MacDonald, D., Abbott, R., \& Jenkins, D. (2012). Physical Activity of Remote Indigenous Australian Women: A Postcolonial Analysis of Lifestyle. Leisure Sciences, 34, 39-54.

Maxwell, H., Stronach, M., Adair, D., \& Pearce, S. (2017). Indigenous Australian women and sport: Findings and recommendations from a parliamentary inquiry. Sport in Society (Online), 1-29. doi:10.1080/17430437.2017.1284802

Mayoux, L. (2000). From Access to Empowerment: Gender Issues in Micro-Finance'. Paper presented at the NGO Women's Caucus Position Paper for CSD-8.

Meier, M. (2015). The value of female sporting role models. Sport in Society, 18(8), 968-982.

Miles, M., \& Huberman, A. (1994). Qualitative data Analysis: an expanded sourcebook, 2 nd ed. Thousand Oaks: Sage Publications.

Misener, L., \& Misener, K. E. (2016). Examining the integration of sport and health promotion: partnership or paradox? International Journal of Sport Policy and Politics, 8(4), 695-712.

Murphy, P., \& Waddington, I. (1998). Sport for all: Some public health issues and problems. Critical Public Health, 8(3), 193-205. doi:http://dx.doi.org/10.1080/09581599808402907

Oakley, P. (2001). Evaluating Empowerment: Reviewing the Concept and Practice. Oxford: INTRAC.

Paraschak, V., \& Thompson, K. (2014). Finding strength(s): Insights on Canadian Aboriginal physical cultural practices. Sport in Society, 17(8), 1046-1060.

Ralph, S. (1997). Working with Aboriginal families: Issues and guidelines for family and child counsellors. Australian Institute of Family Studies, 46, 46-50.

Rowlands, J. (1997). Questioning Empowerment. Oxford: Oxfam.

Sabo, D., Miller, K., Melnick, M., Farrell, M., \& Barnes, G. (2005). High school athletic participation and adolescent suicide: a nationwide US study. International Review for the Sociology of Sport, 40(1), 5-23.

Sen, A. (1985). Commodities and capabilities. New York: Elsevier Science Pub. Co.

Stronach, M., \& Adair, D. (2014). Dadirri: Reflections on a Research Methodology Used to Build Trust Between a Non-indigenous Researcher and Indigenous Participants. Cosmopolitan Civil Societies: An Interdisciplinary Journal, 6(2), 117-134. 
Stronach, M., Maxwell, H., \& Taylor, T. (2015). 'Sistas' and Aunties: Sport, Physical Activity and Indigenous Australian Women. Annals of Leisure Research.

Tonkinson, M. (1988). Sisterhood or Aboriginal Servitude: Black Women and White Women on the Australian Frontier. Aboriginal History, 12(1), 27-42.

Tonts, M. (2005). Competitive sport and social capital in rural Australia. Journal of Rural Studies, 21(2), 137-149.

Tsey, K., \& Haswell-Elkins, M. (2008). Empowerment as a Key to Improving Indigeneous Health and Wellbeing. Brisbane: Cooperative Research Centre for Aboriginal Health.

Tsey, K., Whiteside, M., Haswell-Elkins, M., Bainbridge, R., Cadet-James, Y., \& Wilson, A. (2010). Empowerment and Indigenous Australian Health: a synthesis of findings from Family Wellbeing Formative research. Health and Social Care, 18(2), 169-179. doi:10.1111/j.13652524.2009.00885.x.

Vallance, R., \& Tchacos, E. (2001). Research: A Cultural Bridge. Paper presented at the Australian Association for Research in Education (AARE) Conference, Fremantle.

Van Acker, E. (1999). Different Voices: Gender and Politics in Australia. South Yarra: MacMillan Education Australia Pty Ltd.

Ware, V., \& Meredith, V. (2013). Supporting healthy communities through sports and recreation programs: Resource sheet no. 26. . Retrieved from

Williams, L., Labonte, R., \& O'Brien, M. (2003). Empowering social action through narratives of identity and culture. Health Promotion International, 18(1), 33-40. doi:https://doi.org/10.1093/heapro/18.1.33

Willis, C., Greene, J., Abramowicz, A., \& Riley, B. (2016). Strengthening the evidence and action on multi-sectoral partnerships in public health: an action research initiative. Health Promotion and Chronic Disease Prevention in Canada, 36(6), 101-111.

Willis, E., Reynolds, L., \& Keleher, H. (2016). Understanding the Australian Health Care System (3rd ed.). Chatswood: Elsevier.

Wilson, A. C., \& Yellow Bird, M. (2005). For indigenous eyes only: A decolonization handbook. Santa Fe: School of American Research.

WomenSport International. (1994). The Brighton Declaration on Women and Sport.

World Health Organization. (1948). Constitution of World Health Organization: Principles. New York: World Health Organisation.

World Health Organization. (1986). Ottawa Charter for Health Promotion: World Heath Organization. 


\begin{tabular}{|c|c|c|c|}
\hline $\begin{array}{l}\text { Temporal element of } \\
\text { Agency }\end{array}$ & Themes Identified & Links with empowerment & Example quotation \\
\hline \multirow{7}{*}{$\begin{array}{l}\text { Agency that is } \\
\text { responsive to the } \\
\text { present }\end{array}$} & Building communities & $\begin{array}{l}\text { Women have power to (creating new } \\
\text { possibilities) }\end{array}$ & $\begin{array}{l}\text { it's more just a modern way of getting together, } \\
\text { bringing Aboriginal communities together }\end{array}$ \\
\hline & Team building & Women have power with (acting in a group) & $\begin{array}{l}\text { it's really really empowering to have us all } \\
\text { together and seeing that strength in each other }\end{array}$ \\
\hline & Partnerships & Women have power with (acting in a group) & $\begin{array}{l}\text { I was so proud of the powerful sense of } \\
\text { community and togetherness the Indigenous } \\
\text { people brought to the game }\end{array}$ \\
\hline & $\begin{array}{l}\text { Discrimination and } \\
\text { racism }\end{array}$ & $\begin{array}{l}\text { Women need power over (ability to resist } \\
\text { manipulation) }\end{array}$ & $\begin{array}{l}\text { it's driven primarily by unconscious bias and } \\
\text { systemic racism or systemic barriers if you like }\end{array}$ \\
\hline & Shame & $\begin{array}{l}\text { Women need power from within (enhancing } \\
\text { self-respect and self-acceptance) }\end{array}$ & of course I didn't go back to that class \\
\hline & Gaining strength & $\begin{array}{l}\text { Women have power over (ability to resist } \\
\text { manipulation) }\end{array}$ & Little things like that make me strong \\
\hline & Affordability & $\begin{array}{l}\text { Women need more power to (creating new } \\
\text { possibilities) }\end{array}$ & $\begin{array}{l}\text { I haven't even heard of a golf player or a sport } \\
\text { that we would consider rich }\end{array}$ \\
\hline
\end{tabular}




\begin{tabular}{|c|c|c|c|}
\hline \multirow[t]{4}{*}{$\begin{array}{l}\text { Agency that is directed } \\
\text { toward the future }\end{array}$} & Loving to lead & $\begin{array}{l}\text { Women will continue to have power from } \\
\text { within (enhancing self-respect and self- } \\
\text { acceptance) }\end{array}$ & $\begin{array}{l}\text { I loved leading and being part of a group of } \\
\text { Aboriginal women }\end{array}$ \\
\hline & Role models & $\begin{array}{l}\text { Women need more power to (creating new } \\
\text { possibilities) }\end{array}$ & $\begin{array}{l}\text { you don't really see female role models, } \\
\text { especially in the indigenous community }\end{array}$ \\
\hline & Cultural safety & $\begin{array}{l}\text { Women will continue to have power from } \\
\text { within (enhancing self-respect and self- } \\
\text { acceptance) }\end{array}$ & $\begin{array}{l}\text { It's a safe space for them to come; it's an } \\
\text { Aboriginal organisation. It's run by Aboriginal } \\
\text { people }\end{array}$ \\
\hline & Policies and support & $\begin{array}{l}\text { Women need more power to (creating new } \\
\text { possibilities) }\end{array}$ & $\begin{array}{l}\text { unless there's a concerted specific policy } \\
\text { which supports that and there's infrastructure } \\
\text { around it there seems to be very little which } \\
\text { supports Aboriginal women }\end{array}$ \\
\hline
\end{tabular}




\begin{tabular}{|c|c|c|c|c|c|}
\hline $\begin{array}{l}\text { Organisation } \\
\text { name }\end{array}$ & $\begin{array}{l}\text { Organisation } \\
\text { type }\end{array}$ & $\begin{array}{l}\text { Program name and } \\
\text { description }\end{array}$ & $\begin{array}{l}\text { Health promotion } \\
\text { partnerships }\end{array}$ & $\begin{array}{l}\text { Empowerment features of a } \\
\text { health promotion approach }\end{array}$ & $\begin{array}{l}\text { Health and social } \\
\text { outcomes for Indigenous } \\
\text { women }\end{array}$ \\
\hline $\begin{array}{l}\text { Onkaparinga } \\
\text { Women's } \\
\text { Rugby Club }\end{array}$ & $\begin{array}{l}\text { Community } \\
\text { Sports Club }\end{array}$ & $\begin{array}{l}\text { The Onkaparinga } \\
\text { Women's Rugby Club is } \\
\text { part of the local } \\
\text { community in South } \\
\text { Australia }\end{array}$ & $\begin{array}{l}\text { Partnership with } \\
\text { Onkaparinga Rugby } \\
\text { Union Football Club }\end{array}$ & $\begin{array}{l}\text { - Club is embedded in the } \\
\text { local Indigenous } \\
\text { community } \\
\text { - } \quad \text { Female focus } \\
\text { - Culturally safe space }\end{array}$ & $\begin{array}{l}12 \text { women regularly } \\
\text { participating in an all-female } \\
\text { Indigenous team }\end{array}$ \\
\hline $\begin{array}{l}\text { Softball } \\
\text { Australia }\end{array}$ & $\begin{array}{l}\text { National Sport } \\
\text { Organisation } \\
\text { (NSO) }\end{array}$ & $\begin{array}{l}\text { The Indigenous Softball } \\
\text { Program provides over } \\
100 \text { programs including } \\
\text { Softball competitions, } \\
\text { coaching and officiating } \\
\text { training sessions, and } \\
\text { junior development } \\
\text { activities }\end{array}$ & $\begin{array}{l}\text { Partnership with the } \\
\text { Australian Government } \\
\text { via the Australian Sports } \\
\text { Commission, sponsors, } \\
\text { the States (such as the } \\
\text { Northern Territory's } \\
\text { Indigenous Sports Unit } \\
\text { and local participating } \\
\text { Shires), National }\end{array}$ & $\begin{array}{l}\text { - Leadership opportunities } \\
\text { for Indigenous women and } \\
\text { girls as players, coaches, } \\
\text { umpires, administrators } \\
\text { and volunteers are } \\
\text { provided } \\
\text { Partnerships are } \\
\text { established with }\end{array}$ & $\begin{array}{l}73 \% \text { female Indigenous } \\
\text { participation in softball } \\
\text { activity from } 7800 \text { total } \\
\text { Indigenous participation } \\
\text { A participant explained: } \\
\text { I was so proud of the } \\
\text { powerful sense of } \\
\text { community and }\end{array}$ \\
\hline
\end{tabular}




\begin{tabular}{|c|c|c|c|c|c|}
\hline & & & $\begin{array}{l}\text { Aboriginal Sporting } \\
\text { Chance Academy } \\
\text { (NASCA) and the } \\
\text { Indigenous community }\end{array}$ & $\begin{array}{l}\text { government, Indigenous } \\
\text { organisations (such as } \\
\text { Red Dust) and a range of } \\
\text { sporting bodies }\end{array}$ & $\begin{array}{l}\text { togetherness the Indigenous } \\
\text { people brought to the game } \\
\text { and this is exactly what we } \\
\text { can bring to Softball. }\end{array}$ \\
\hline $\begin{array}{l}\text { Hockey } \\
\text { Queensland } \\
\text { (HQ) }\end{array}$ & $\begin{array}{l}\text { State Sport } \\
\text { Organisation } \\
\text { (SSO) }\end{array}$ & $\begin{array}{l}\text { Women's Sport } \\
\text { Leadership Program is } \\
\text { designed to equip } \\
\text { women in remote } \\
\text { Indigenous communities } \\
\text { with sport management } \\
\text { and administration skills }\end{array}$ & $\begin{array}{l}\text { Partnership with The } \\
\text { Remote Indigenous } \\
\text { Hockey Program } \\
\text { (RIHP)and Hockey } \\
\text { Australia }\end{array}$ & $\begin{array}{l}\text { - Hockey is delivered in } \\
\text { traditional languages } \\
\text { - Equipment is decorated } \\
\text { with traditional Indigenous } \\
\text { art } \\
\text { - Indigenous leadership } \\
\text { throughout the program } \\
\text { Networks between } \\
\text { sporting organisations at } \\
\text { national, state and local } \\
\text { level }\end{array}$ & $\begin{array}{l}\text { 2010-2011, the Hockey } \\
\text { Queensland } \\
\text { Remote and Indigenous } \\
\text { Program secured funding for } \\
\text { the employment of two } \\
\text { young Indigenous girls. } \\
\text { An organiser stated that HQ: } \\
\text { Embraces diversity and } \\
\text { modify programs to suit the } \\
\text { Iocal needs of the } \\
\text { community ... The Remote } \\
\text { Indigenous Hockey Program } \\
\text { (RIHP) has modified the } \\
\text { HOCKEY ED Program to }\end{array}$ \\
\hline
\end{tabular}




\begin{tabular}{|c|c|c|c|c|c|}
\hline & & & & & $\begin{array}{l}\text { ensure it is designed to } \\
\text { meet the needs of the } \\
\text { indigenous communities. }\end{array}$ \\
\hline $\begin{array}{l}\text { David } \\
\text { Wirrpunda } \\
\text { Foundation }\end{array}$ & $\begin{array}{l}\text { Philanthropic } \\
\text { Organisation }\end{array}$ & $\begin{array}{l}\text { The Deadly Sistas Girlz } \\
\text { Program aims to } \\
\text { empower Aboriginal } \\
\text { girls aged } 8 \text { to } 17 \text { years. } \\
\text { It addresses issues of } \\
\text { self-esteem, healthy } \\
\text { relationships, sexual } \\
\text { and women's health, } \\
\text { alcohol and other drug } \\
\text { use, healthy lifestyles, } \\
\text { and future directions } \\
\text { and opportunities. }\end{array}$ & $\begin{array}{l}\text { Partnerships with specific } \\
\text { school sites }\end{array}$ & $\begin{array}{l}\text { - } \text { Girls are personally } \\
\text { mentored throughout the } \\
\text { program } \\
\text { - Girls make positive social } \\
\text { interactions with their } \\
\text { fellow Sista girls in a fun } \\
\text { and caring environment. } \\
\text { The program offers a safe, } \\
\text { stable and trusting } \\
\text { environment } \\
\text { Aboriginal female role } \\
\text { models }\end{array}$ & $\begin{array}{l}\text { 2,500 Indigenous girls } \\
\text { participated in } 4.5 \text { years. } \\
\text { A Deadly Sistas Girlz } \\
\text { Program Coordinator } \\
\text { articulated that: } \\
\text { I always looked forward to } \\
\text { playing sports throughout } \\
\text { the week. We were like a } \\
\text { little family ... We were able } \\
\text { to be competitive in a safe } \\
\text { environment whilst also } \\
\text { having fun and being social } \\
\text { with other community } \\
\text { members. Playing sports, } \\
\text { namely netball, taught me a }\end{array}$ \\
\hline
\end{tabular}




\begin{tabular}{|c|c|c|c|c|c|}
\hline & & & & & $\begin{array}{l}\text { lot about my strengths, how } \\
\text { to work with other people, } \\
\text { having good communication } \\
\text { and self-discipline }\end{array}$ \\
\hline $\begin{array}{l}\text { David } \\
\text { Wirrpunda } \\
\text { Foundation }\end{array}$ & $\begin{array}{l}\text { Philanthropic } \\
\text { Organisation }\end{array}$ & $\begin{array}{l}\text { Gwabba Yorga, Gabba } \\
\text { Warra (GYGW) } \\
\text { program is a program } \\
\text { for Indigenous teenage } \\
\text { girls which focuses on } \\
\text { increasing awareness } \\
\text { about the effects of } \\
\text { binge drinking. }\end{array}$ & $\begin{array}{l}\text { Partnership with Netball } \\
\text { Western Australia and } \\
\text { Commissioner for } \\
\text { Children and Young } \\
\text { People Western Australia } \\
\text { (WA) }\end{array}$ & $\begin{array}{l}\text { Positive female } \\
\text { Indigenous role models }\end{array}$ & $\begin{array}{l}\text { A greater awareness of the } \\
\text { problem of binge drinking on } \\
\text { the health of Indigenous } \\
\text { people }\end{array}$ \\
\hline $\begin{array}{l}\text { David } \\
\text { Wirrpunda } \\
\text { Foundation }\end{array}$ & $\begin{array}{l}\text { Philanthropic } \\
\text { Organisation }\end{array}$ & $\begin{array}{l}\text { Moorditj Mums is a pilot } \\
\text { program aimed at } \\
\text { young mums to } \\
\text { encourage better } \\
\text { parenting and pathways } \\
\text { to education and } \\
\text { employment. }\end{array}$ & $\begin{array}{l}\text { Partnership with Moorditj } \\
\text { Aboriginal Health and } \\
\text { Wellness Centre } \\
\text { Aboriginal Education } \\
\text { Officers plus } \\
\text { School Principals }\end{array}$ & $\begin{array}{l}\text { - } \text { Positive female } \\
\text { Indigenous role models } \\
\text { - } \quad \text { Mentoring }\end{array}$ & $\begin{array}{l}\text { Participation of } 9 \text { women } \\
\text { The Moorditj Mums Program } \\
\text { Manager stated: } \\
\text { Sport is a way of } \\
\text { community, being a part of a } \\
\text { club can give you a sense of }\end{array}$ \\
\hline
\end{tabular}




\begin{tabular}{|c|c|c|c|c|c|}
\hline & & & & & $\begin{array}{l}\text { belonging. The friendships } \\
\text { made through sport are } \\
\text { mostly positive, meaning } \\
\text { that your positive influences } \\
\text { in your life and it is proven } \\
\text { that sport improves mental } \\
\text { health, as well as physical } \\
\text { health. }\end{array}$ \\
\hline VicHealth & $\begin{array}{l}\text { Government } \\
\text { Health } \\
\text { Organisation }\end{array}$ & $\begin{array}{l}\text { Surfing Victoria's } \\
\text { Indigenous Surfing } \\
\text { Program }\end{array}$ & $\begin{array}{l}\text { Surfing Victoria, Play it } \\
\text { Safe by the Water } \\
\text { (Victorian Government), } \\
\text { Sport and Recreation } \\
\text { Victoria, Wathaurong } \\
\text { Aboriginal Cooperative } \\
\text { (Geelong) and the surfing } \\
\text { industry }\end{array}$ & $\begin{array}{l}\text { VicHealth partners with } \\
\text { SSOs, Regional sports } \\
\text { organisations and local } \\
\text { clubs to empower } \\
\text { Indigenous sport }\end{array}$ & $\begin{array}{l}\text { A statewide Indigenous } \\
\text { Surfing Program which } \\
\text { engaged over } 1500 \\
\text { community members in } 12 \\
\text { months. } \\
\text { Included a 12-month } \\
\text { traineeship for young people } \\
\text { to work in the surf industry } \\
\text { and related aquatic/ } \\
\text { recreation industries }\end{array}$ \\
\hline
\end{tabular}




\begin{tabular}{|c|c|c|c|c|c|}
\hline VicHealth & $\begin{array}{l}\text { Government } \\
\text { Health } \\
\text { Organisation }\end{array}$ & $\begin{array}{l}\text { Fitzroy Stars Football } \\
\text { and Netball Club }\end{array}$ & $\begin{array}{l}\text { Fitzroy Stars Football and } \\
\text { Netball Club (community } \\
\text { sports club) }\end{array}$ & $\begin{array}{l}\text { 'Community centered } \\
\text { practice' - community } \\
\text { owned and driven, builds } \\
\text { on strengths to address } \\
\text { community priorities } \\
\text { Co-creation of programs }\end{array}$ & $\begin{array}{l}\text { The sports club nurtured } \\
\text { Indigenous culture that } \\
\text { promotes a healthy lifestyle, } \\
\text { fitness, nutrition and self- } \\
\text { esteem and build bridges } \\
\text { between Aboriginal and non- } \\
\text { Aboriginal communities and } \\
\text { provided pathways to } \\
\text { employment for Aboriginal } \\
\text { people. }\end{array}$ \\
\hline
\end{tabular}




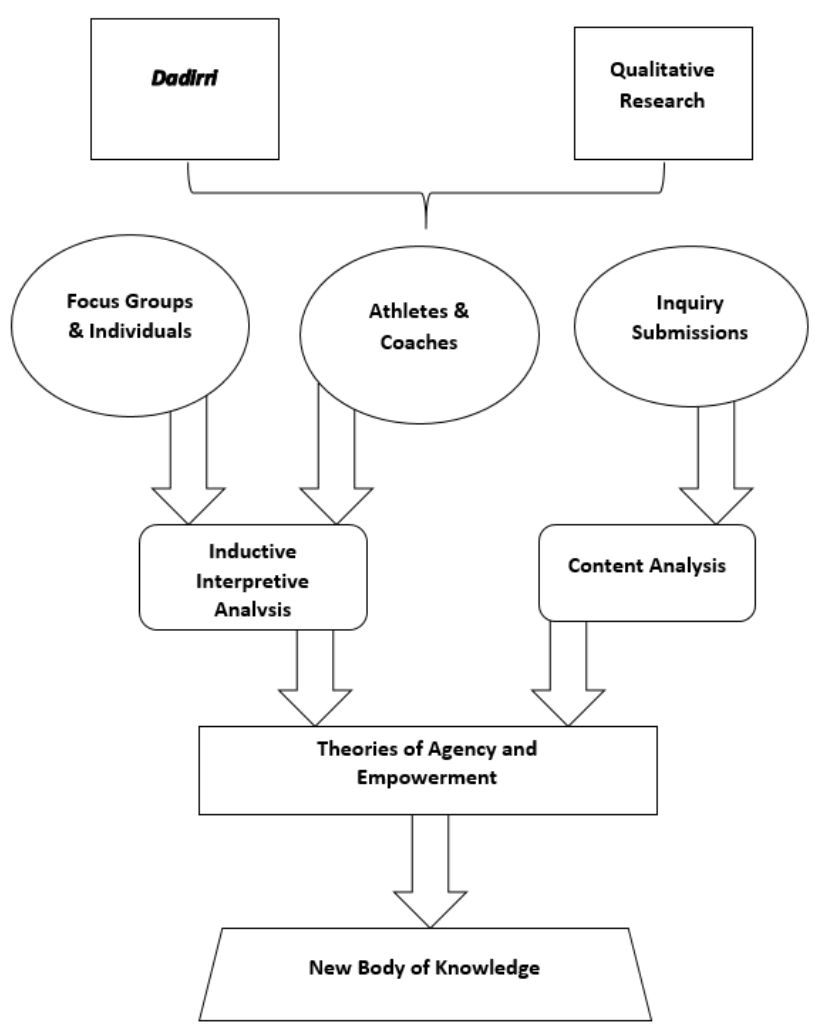

Figure 1: Data analysis process 